\title{
PENGARUH PEMANFAATAN DANA ZAKAT PRODUKTIF TERHADAP TINGKAT PENDAPATAN MUSTAHIK PADA BAZNAS KOTA PALOPO
}

\author{
Nurhasanah \\ Jurusan Akuntansi, Universitas Muhammadiyah Palopo \\ nurhasanah9723@yahoo.com
}

\begin{abstract}
ABSTRAK
Penelitian ini bertujuan untuk mengetahui seberapa besar pemanfaatan dana zakat produktif berpengaruh terhadap tingkat pendapatan para mustahiknya di BAZNAS Kota Palopo. Adapun metode yang digunakan dalam penelitian ini adalah metode deksripsi kuantitatif dengan menggunakan persamaan regresi linear sederhana $Y=a+b X+e$ dengan jumlah sampel penelitian sebanyak 69 responden. Pengumpulan data menggunakan angket kuesioner untuk mengetahui data $X$ dan data $Y$. Adapun hasil penelitian yang diperoleh adalah pemanfaatan dana zakat produktif $(X)$ mempunyai pengaruh yang signifikan terhadap tingkat pendapatan mustahik $(Y)$ pada BAZNAS Kota Palopo. Hal ini dapat di lihat dari hasil uji T (parsial) dimana diperoleh nilai signifikan sebesar 0,000 lebih kecil daripada 0,05 yang berarti membuktikan hipotesis $\mathrm{Hl}$ diterima bahwa ada pengaruh signifikan pemanfaatan dana zakat produktif mempunyai pengaruh terhadap tingkat pendapatan mustahik pada BAZNAS Kota Palopo dan nilai $R$ square yang diperoleh sebesar 0,411 menunjukkan bahwa pemanfaatn dana zakat produktif pada BAZNAS Kota Palopo 41,1\% berpengaruh terhadap tingkat pendapatan mustahik sementara sisanya dipengaruhi oleh variabel lain.
\end{abstract}

Kata Kunci: Zakat, Mustahik, Baznas

\section{ABSTRACT}

This study aims to determine how much the utilization of productive zakat funds affect the level of income of the mustahik in BAZNAS Palopo City. The method used in this research is quantitative descriptive method using simple linear regression equation $Y=a+b X+e$ with a total sample of 69 respondents. Data collection using questionnaire questionnaire to find out the data $X$ and $Y$ data. The research results obtained are the use of productive zakat funds $(X)$ has a significant influence on the level of income mustahik $(Y)$ in BAZNAS Palopo City. This can be seen from the results of the T test (partial) which obtained a significant value of 0,000 smaller than 0.05, which means that the hypothesis $\mathrm{HI}$ is accepted that there is a significant influence on the utilization of productive zakat funds has an influence on the level of mustahik income in the Palopo BAZNAS and the value of The R square obtained by 0.411 shows that the use of productive zakat funds in BAZNAS in Palopo City $41.1 \%$ influences the level of mustahik income while the rest is influenced by other variables.

Keywords: Zakat, Mustahik, Baznas

\section{PENDAHULUAN}

Keberadaan Indonesia sebagai negara berkembang tidak dapat lepas dari banyaknya permasalahan dibidang ekonomi. Salah satu permasalahan nyata yang dihadapi bangsa Indonesia adalah kemiskinan dan pengangguran.

Zakat merupakan salah satu pendekatan Islam dalam pengentasan kemiskinan dan pencapaian pemerataan kesejahteraan, solusi yang mampu mengurangi beban hidup bagi orang yang tidak mampu (fakir miskin) dan menjadi bagian ibadah bagi orang yang mampu (kaya). (Nafiah, 2015). Pengelolaan dana zakat dalam rangka pengembangan ekonomi umat, perlu diarahkan sebagai sarana pemerataan kemakmuran rakyat dan pemecahan masalah kemiskinan umat. 
Indonesia merupakan suatu negara dengan mayoritas penduduk beragama Islam sekitar 87,18\% dari 237.641.326 penduduk Indonesia (Badan Pusat Statistik, 2018). Secara otomatis potensi jumlah dan pendayagunaan zakat di Indonesia khususnya dalam upaya meningkatkan kesejahteraan sangatlah besar. Potensi tersebut tentunya telah disadari oleh pemerintah, hal ini terlihat dengan adanya dasar hukum/Undang-Undang tentang zakat yang salah satu diantaranya adalah Undang-Undang Nomor 23 Tahun.

2011 tentang Pengelolaan Zakat, yang sebelumnya memakai Undang-Undang Nomor 38 Tahun 1999 . Untuk mendorong terlaksananya Undang- Undang tersebut pemerintah juga telah memfasilitasi dengan dibentuknya BAZNAS yang bertugas untuk mengelola zakat, infaq dan sedekah di setiap daerah yang berada di wilayah Indonesia. (Nafiah, 2015).

Pendapatan dan pengeluaran dalam ranah ekonomi Islam salah satunya diatur melalui mekanisme zakat. Pembaharuan zakat menjadi penting untuk dilakukan, karena selama ini sebagian besar umat masih memandang zakat sebagai ibadah yang terlepas kaitannya dengan persoalan ekonomi dan sosial, maka saat ini zakat harus dipandang sebagai sumber kekuatan ekonomi umat yang dapat dipergunakan untuk menyelesaikan berbagai permasalah sosial umat Islam.

Esensi dari zakat sendiri adalah selain untuk memenuhi kebutuhan konsumtifnya juga memenuhi segala kebutuhan hidupnya termasuk pendidikan, tempat tinggal dan sandang mereka. Dari sinilah pola pemberian zakat kepada para mustahik tidak hanya bersifat konsumtif saja, namun dapat pula bersifat produktif. pendayagunaan zakat secara produktif yang pemahamannya lebih kepada bagaimana cara atau metode menyampaikan dana zakat kepada sasaran dalam pengertian yang luas, sesuai dengan tujuan syara'.(Sartika M, 2008).

Potensi zakat Kota Palopo jika ditinjau dari aspek ekonomis potensinya sangat besar, dengan jumlah penduduk sebanyak 172.916 jiwa (termasuk golongan masyarakat miskin), $82.27 \%$ atau sekitar 125.047 orang beragama islam (Badan Pusat Statistik, 2017) Baznas palopo mendistribusikan dana ZIS tahun 2018 sebesar Rp.3.200.000.000 kepada 77.617 orang penerima manfaat, diantaranya pendistribusian zakat produktif sebesar Rp.544.500.000 untuk 223 mustahik. Dari data tersebut bisa dikatakan bahwa dengan adanya zakat produktif ini dapat meningkatkan pendapatan mustahik dan diharapkan setiap tahunnya dapat meningkat. (BAZNAS, 2018). 
Zakat merupakan ibadah sosial yang telah diwajibkan oleh Allah kepada setiap hambanya. Lima rukun Islam sebagai rangkaian saling terkait yang diwajibkan kepada setiap mereka yang beragama Islam seperti Syahadat, Sholat, Zakat, Puasa dan Haji bagi yang mampu, memiliki tata cara yang berbeda dalam pelaksanaannya. Dengan zakat, Islam telah menunjukkan semangat sosial dan perlindungan antara mereka yang kaya untuk memperhatikan mereka yang miskin sehingga tidak adanya ketimpangan sosial. Sebagaimana Islam memandang setiap manusia adalah sama dihadapan Allah.(Syafiq, 2015).

Untuk memaksimalkan potensi zakat dalam upaya peningkatkan pendapatan mustahik, pengelolaan zakat sekarang ini dilakukan dengan dua cara, yaitu pengelolan zakat secara konsumtif dan produktif. Pengelolaan zakat secara konsumtif yaitu pengumpulan dan pendistibusian yang dilakukan dengan tujuan memenuhi kebutuhan dasar ekonomi para mustahik berupa pemberian bahan makanan dan lain- lain serta bersifat pemberian untuk dikonsumsi secara langsung, sedangkan pengelolaan zakat produktif yaitu pengelolaan zakat dengan tujuan pemberdayaan dan biasa dilakukan dengan cara bantuan modal pengusaha, pembinaan, pendidikan gratis dalam bentuk beasiswa, dan pelayanan kesehatan gratis (Andri, 2009).

Zakat produktif merupakan zakat yang diberikan kepada mustahik berupa modal usaha atau yang lainnya yang digunakan untuk usaha produktif yang mana hal ini akan meningkatkan taraf hidupnya, dengan harapan seorang mustahik akan bisa menjadi muzakki jika dapat menggunakan harta zakat tersebut untuk usahanya.(Utami. S, 2016) Zakat yang diberikan kepada mustahik akan berperan sebagai pendukung peningkatan ekonomi mereka apabila disalurkan pada kegiatan produktif. Dengan berkembangnya usaha kecil menengah dengan modal yang berasal dari zakat akan menyerap tenaga kerja dan berkembangnya usaha para mustahik. Hal ini berarti angka pengangguran bisa dikurangi, berkurangnya angka pengangguran akan berdampak pada meningkatnya daya beli masyarakat terhadap suatu produk barang atau jasa, meningkatkan daya beli masyarakat akan diikuti oleh pertumbuhan produksi, pertumbuhan sektor produksi inilah yang akan menjadi salah satu indikator adanya pertumbuhan ekonomi.

Pengembangan zakat bersifat produktif dengan cara dijadikannya dana zakat sebagai modal usaha, untuk pemberdayaan ekonomi penerimanya, dan supaya fakir miskin dapat menjalankan atau membiayai kehidupannya secara konsisten. Dengan dana zakat tersebut fakir miskin akan 
mendapatkan penghasilan tetap,meningkatkan usaha, mengembangkan usaha serta mereka dapat menyisihkan penghasilannya untuk menabung.

\section{Rumusan Masalah}

Berdasarkan latar belakang sebagaimana telah diuraikan di atas, maka rumusan masalah dalam penelitian ini adalah Apakah pemanfaatan dana zakat produktif berpengaruh terhadap tingkat pendapatan para mustahiknya pada Badan Amil Zakat Nasional (BAZNAS) Kota Palopo ?

\section{Tujuan Penelitian}

Adapun tujuan dari penelitian ini adalah untuk mengetahui Pemanfaatan dana zakat produktif berpengaruh terhadap tingkat pendapat mustahiknya pada Badan Amil Zakat Nasional (BAZNAS) Kota Palopo.

\section{TINJAUAN PUSTAKA}

\section{Syariah Enterprise Theory}

Syariah Enterprise Theory tidak mendudukkan manusia sebagai pusat dari segala sesuatu sebagaimana dipahami oleh antroposentrisme. Tapi sebaliknya, Syariah Enterprise Theory menempatkan Tuhan sebagai pusat dari segala sesuatu. Tuhan menjadi pusat tempat kembalinya manusia dan alam semesta. Oleh karena itu, manusia di sini hanya sebagai wakilNya (khalituLlah fil $\operatorname{ardh}$ ), sebagai perpanjangan tangan yang memiliki konsekuensi patuh terhadap semua hukumhukum Tuhan. Artinya sebagai khalifatullah fil ardh manusia memiliki misi mulia yaitu menciptakan dan mendistribusikan kesejahteraan (materi dan nonmateri) bagi seluruh manusia dan alam semesta, untuk mempermudah tugas ini manusia dapat menciptakan organisasi (organisasi profit atau organisasi nonprofit) yang digunakan sebagai instrumen dalam mengemban tugas tersebut sehingga organisasi diharuskan mempertanggung jawabkan seluruh aktivitas kepada Allah secara vertikal, dan kemudian dijabarkan lagi dalam bentuk pertanggungjawaban secara horizontal kepada umat manusia lain serta pada lingkungan alam (Kalbarini \& Suprayogi, 2014) 


\section{Teori Clifford Geertz}

Teori Clifford Geertz, yang menyatakan bahwa Geertz, tentang motivasi agama perlu ditambahkan. Geertz memberikan definisi tentang agama (religion) sebagai berikut (Geertz, 1973) :

a. Sebuah sistem simbol yang berperan;

b. Membangun suasana hati (kenyamanan) dan motivasi yang kuat, meresap dalam hati (pervasive) dan bertahan dalam diri manusia, dengan (melalui suatu cara/metode);

c. Merumuskan konsep tatanan kehidupan yang umum;

d. Mengemas konsep-konsep ini secara faktual;

e. Suasana hati dan motivasi tampak realistis secara unik.

Uraian Geertz di atas mengandung makna bahwa motivasi yang kuat salah satu cara atau metode yang dapat membangun suasana hati dan membentuk sebuah motivasi yang kuat. Hal itu dilakukan dengan melalui suatu cara/metode, yang dalam hal ini adalah melalui pemberian zakat oleh muzakki ke lembaga zakat. Sebagai seorang muslim, tentu akan lebih termotivasi, seandainya ia menunaikan zakatnya ke Lembaga zakat. Bahkan menurut Geertz, suasana hati dan motivasi tersebut tidak hanya sekedar ada dalam hati, tetapi tampak realistis dan unik. Oleh karenanya, tidak mengherankan seandainya didapati banyak lembaga zakat, yayasan sosial, masjid atau mushalla, dan sejenisnya, yang kemudian mengelola zakat para muzakki, sebagai bentuk lahiriah dari suasana hati dan motivasi yang ada dalam diri seseorang muzakki. Itulah bentuk keunikan dan realisasi dari motivasi kuat yang ada dalam diri seorang muzakki.(Muthohar, 2016)

\section{Pemanfaatan Dana Zakat Produktif}

Zakat merupakan pungutan wajib atas individu yang memiliki harta wajib zakat yang melebihi nishab (muzakki), dan didistribusikan kepada delapan golongan penerima zakat (mustahik), yaitu: fakir, miskin, fisabilillah, ibnussabil, amil, gharimin, hamba sahaya, dan muallaf.(Ascarya, 2006)

Di dalam Al-qur'an terdapat beberapa kata, yang walaupun mempunyai arti yang berbeda dengan zakat, tetapi kadangkala dipergunakan untuk menunjukkan makna zakat, yaitu infak, sedekah dan hak, sebagaimana dinyatakan dalam surah at-Taubah: 34,60 dan 103 serta surah al-An'aam: 141, dipergunakan kata-kata tersebut dengan maksud zakat, karena memiliki kaitan yang sangat kuat dengan zakat. Zakat disebut infak (at-Taubah:34) karena hakikatnya zakat itu adalah penyerahan 
harta untuk kebajikan-kebajikan yang diperintahkan Allah SWT. Disebut sedekah (at-Taubah: 60 dan 103) karena dalah untuk mendekatkan diri (taqarrub) kepada Allah SWT yang harus diberikan kepada mereka yang berhak menerimanya (Hafidhuddin. D, 2002).

Delapan golongan yang berhak menerima zakat sebagaimana yang dimuat dalam QS At-Taubah: 60, dalam buku andri soemitra yaitu :

a. Fakir

Fakir yaitu orang yang tidak berharta dan tidak pula mempunyai pekerjaan atau usaha tetap guna mencukupi kebutuhan hidupnya (nafkah), sedangkan orang yang menanggungnya (menjamin hidupnya) tidak ada.

b. Miskin

Miskin yaitu orang yang tidak dapat mencukupi kebutuhan hidupnya, meskipun ia memiliki pekerjaan atau usaha tetap, tetapi hasil usahanya itu belum mencukupi kebutuhannya, dan orang yang menanggungnya tidak ada.

c. Amil

Amil yaitu mereka (panitia atau organisasi) yang melaksanakan segala kegiatan urusan zakat, baik mengumpulkan, membagikan (kepada para mustahik) maupun mengelolanya. Allah menyediakan upah bagi mereka (amilin) dari harta zakat sebanyak imbalan, dan tidak diambil selain harta zakat.

d. Muallaf

Muallaf yaitu orang yang masih lemah imamnya karena baru memelauk agama Islam atau ada orang yang ada keinginan untuk masuk Islam tetapi masih ragu-ragu. Dengan bagian zakat, dapat memantapkan hatinya di dalam Islam.

e. Riqab

Riqab secara bahasa berarti budak belian yang harus di merdekakan. Jadi, riqab adalah hamba sahaya yang perlu diberikan bagian zakat agar mereka dapat melepaskam diri dari belenggu perbudakan.

f. Gharim

Gharim yaitu orang yang punya hutang karena sesuatu kepentingan yang bukan untuk perbuatan maksiat dan ia tidak mampu untuk membaryar atau melunasinya.

g. Sabilillah 
Sabilillah yaitu usaha-usaha yang tujuannya untuk meningkatkan atau meninggikan syiar Islam, seperti membela atau mempertahankan agama, mendirikan tempat ibadah, pendidikan, rumah sakit, dan lain-lain.

h. Ibnu Sabil

Ibnu Sabil yaitu orang yang kehabisan bekal dalam perjalanan dengan maksud baik. Singkatnya orang musafir yang memerlukan bantuan.

Dalam pendistibusiannya diperlukan adanya lembaga amil zakat yang amanah dan kredibel yang mampu untu me-manage distribusi ini. Sifat amanah berarti berani bertanggung jawab terhadap segala aktifitas yang dilaksanakannya terkandung didalamnya sifat jujur. Sedangkan professional adalah sifat mampu untuk melaksanakan tugas yang dibebankan kepadanya dengan modal keilmuan yang ada.(Hafidhuddin. D, 2002).

Pola pendistibusian zakat produktif haruslah diatur sedemikian rupa sehingga jangan sampai sasaran dari program ini tidak tercapai. Beberapa langkah berikut menjadi acuan dalam pendistibusian zakat produktif :

a. Forecasting yaitu meramalkan, memproyeksikan dan mengadakan taksiran sebelum pemberian zakat tersebut.

b. Planning yaitu merumuskan dan merencanakan suatu tindakan tentang apa saja yang akan dilaksanakan untuk tercapainya program

c. Organizing dan Leading, yaitu mengumpulkan berbagai elemen yang akan membawa kesuksesan program termasuk di dalamnya membuat peraturan yang baku yang harus di taati.

d. Controling yaitu pengawasan terhadap jalannya program sehingga jika ada sesuatu yang tidak beres atau menyimpang dari produser akan segera terdeteksi.

\section{Tingkat Pendapatan Mustahik}

Pendapatan adalah uang yang diterima oleh perorangan, perusahaan dan orang lain dalam bentuk upah, gaji, sewa, bunga, komisi, ongkos dan laba (Mahmudi, 2015). Suroto juga mengemukakan pendapatnya tentang definisi pendapatan, menurutnya pendapatan adalah seluruh penerimaan baik berupa uang maupun barang yang berasal dari pihak lain maupun dari hasil industri yang dinilai atas dasar jumlah uang dari harta yang belalu saat itu. Dengan demikian merupakan penghasilan 
yang diterima oleh seseorang dalam jangka waktu tertentu dari hasil usaha yang diperoleh oleh individu atau kelompok yang digunakan untuk memenuhi kebutuhan sehari-harinya.

Oleh karena itu seseorang seharusnya dapat memaksimalkan pendapatan, sehingga pendapatan tersebut secara langsung maupun tidak langsung dapat memenuhi kebutuhan sehari-harinya. Demikian pula pendapatan dapat digunakan untuk menentukan atau mengukur tingkat kesejahteraan seseorang. Seseorang dikatakan sejahtera jika mampu memenuhi kebutuhannya dengan baik, dalam artian bahwa pengeluaran harus dapat disesuaikan dengan pemasukan.

Secara umum, perekonomian seseorang baru dapat dikatakan berkembang apabila pendapatan perkapita seseorang tersebut terus menunjukkan kecenderungan jangka panjang yang naik. Semakin tinggi pendapatan seseorang, maka semakin kecil pula proporsi penduduknya yang berpenghasilan dibawah garis kemiskinan. Oleh karena itu analisis pendapatan dapat dirumuskan sebagai berikut:

$$
\begin{aligned}
& \mathrm{Y}=\mathrm{TR}-\mathrm{TC} \text { Keterangan: } \\
& \mathrm{Y} \quad \text { : Income (Pendapatan) } \\
& \mathrm{TR}: \text { Total Revenue (Total pendapatan kotor) } \\
& \mathrm{TC}: \text { Total Cost (Total biaya yang dikeluarkan) }
\end{aligned}
$$

Dengan demikian pendapatan merupakan hasil pengurangan total jumlah penerimaan dengan biaya yang dikeluarkan, dimana total pendapatan merupakan penjumlahan dari seluruh pendapatan yang diperoleh dari hasil usaha yang dilakukan.

Pendapatan adalah seluruh penerimaan baik berupa uang maupun barang yang berasal dari pihak lain maupun dari pihak industri yang dinilai atas dasar jumlah uang dari harta yang berlalu saat itu. Berdasarkan definisi tersebut, maka pendapatan dapat diklasifikasikan menjadi dua bagian yaitu:

a. Pendapatan dari sektor formal: Pendapatan ini biasanya berupa gaji atau upah yang diperoleh secara tetap.

b. Pendapatan dari sektor nonformal/informal: Pendapatan ini berupa penghasilan dagang, tukang, buruh, dll. Pendapatan ini biasanya berupa uang yang diterima maupun barang sebagai balas jasa pada sektor informal. Pendapatan ini dapat berupa 
pendapatan dari usaha, pendapatan dari hasil investasi, maupun pendapatan dari keuntungan sosial.

c. Pendapatan dari sektor subsisten: pendapatan ini merupakan hasil usaha sendiri yang berupa tanaman dan ternak.

\section{METODE PENELITIAN}

\section{Jenis dan Sumber Data}

Jenis data yang digunakan dalam penelitian ini merupakan data kuantitatif yakni data yang berupa angka-angka. Sumber data dalam penelitian ini adalah Data Primer yaitu data lapangan yang dapat diperoleh melalui kuesioner.

\section{Populasi dan Sampel}

Populasi dalam penelitian ini adalah penerima zakat produktif (mustahik) pada Badan Amil Zakat Nasional (BAZNAS) Kota Palopo.

Sampel yang akan dipilih yakni mustahik pada Badan Amil Zakat Nasional (BAZNAS) Kota Palopo. Teknik pemilihan sampel dalam penelitian ini menggunakan metode nonprobabilitas sampling yaitu metode pemilihan sampel dimana setiap anggota populasi tidak mempunyai peluang yang sama untuk dipilih menjadi sampel (Indriantoro, 2013). Dengan cara sampel menggunakan metode convience sampling yakni metode pengambilan sampel yang didasarkan pada pemilihan anggota populasi yang mudah diakses untuk memperoleh jawaban atau informasi. Pengambilan sampel diperoleh berdasarkan rumus slovin.

\section{Metode Analisis Data}

Teknik analisis yang digunakan dalam penelitian ini meliputi Uji Kualitas Data (Uji Validitas dan Reliabilitas ) dan Uji Hipotesis (Uji Koefisien Determinasi $\mathrm{R}^{2}$, Uji Parsial).

\section{HASIL DAN PEMBAHASAN}

\section{Hasil Penelitian}

Uji Hipotesis dalam penelitian ini menggunakan analisis regresi linear sederhana yang meliputi uji koefisien determinasi $\left(\mathrm{R}^{2}\right)$, uji parsial (uji t) pengujian ini dilakukan untuk menguji hubungan 
antar variabel penelitian, mengetahui besarnya pengaruh masing-masing variabel bebas terhadap variabel terikat.

Ringkasan hasil analisis regresi sederhana disajikan pada tabel 4.10 dibawah ini :

Tabel 4.10

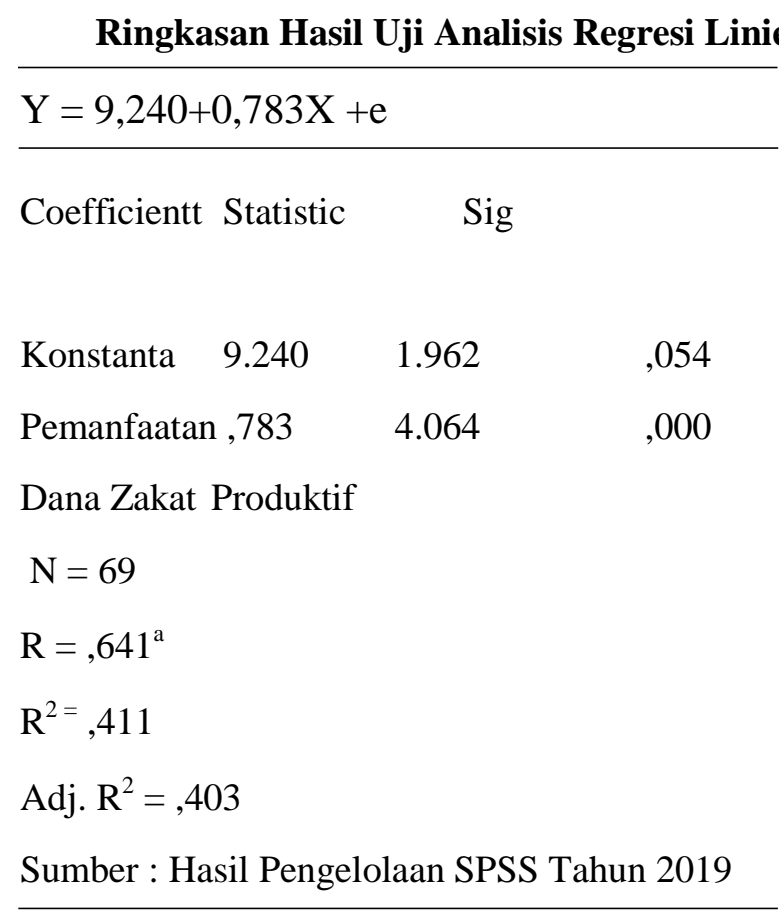

\section{Analisis Regresi Linear Sederhana}

Analisis regresi linear sederhana digunakan untuk menghitung besarnya pengaruh antara variabel independen yaitu pemanfaatan dana zakat produktif terhadap tingkat pendapatan mustahik. Dari tabel 4.10 dapat dilihat model persamaan regresi sederhana dengan menggunakan SPSS yaitu Unstandardized Coefficients, Hal tersebut akan dianalisis sesuai penjelasan berikut ini:

a. Nilai konstanta untuk persamaan regresi sederhana berdasarkan perhitungan statistik di atas sebesar 9.240 artinya apabila variabel bebas bernilai nol maka tingkat pendapatan mustahik pada baznas kota palopo tetap sebesar 9.240.

b. Nilai koefisien sebesar 0,783 menunjukkan bahwa pengaruh pemanfaatan dana zakat produktif $(\mathrm{X})$ terhadap tingkat pendapatan mustahik $(\mathrm{Y})$ adalah positif atau searah, artinya setiap peningkatan variabel pemanfaatan dana zakat produktif regresi menghasilakn nilai sebesar 0,403 . nilai korelasi atau hubungan $(\mathrm{R})$ yaitu sebesar 0,641 dan besarnya persentase pengaruh variabel bebas atau pemanfaatan dana zakat produktif Nurhasanah $33 \mid 38$ 
dengan variabel terikat atau tingkat pendapatan mustahik yang disebut koefisien determinasi ( $R$ Square) sebesar 0,411 atau 41,1\%. Artinya pengaruh pemanfaatan dana zakat produktif terhadap tingkat pendapatan mustahik adalah sebesar 41,1\%, sedangkan sisanya dipengaruhi oleh faktor lain.

\section{Hasil uji koefisien determinasi $\left(\mathbf{R}^{2}\right)$}

Dari tabel 4.10 koefisien determinasi yang ditunjukkan oleh Adj, R dari persamaan regresi menghasilkan nilai sebesar 0,403. nilai korelasi atau hubungan $(\mathrm{R})$ yaitu sebesar 0,641 dan besarnya persentase pengaruh variabel bebas atau pemanfaatan dana zakat produktif dengan variabel terikat atau tingkat pendapatan mustahik yang disebut koefisien determinasi ( $R$ Square) sebesar 0,411 atau $41,1 \%$. Artinya pengaruh pemanfaatan dana zakat produktif terhadap tingkat pendapatan mustahik adalah sebesar $41,1 \%$, sedangkan sisanya dipengaruhi oleh faktor lain.

\section{Hasil Uji Parsial (Uji t)}

Uji t bertujuan untuk menguji pengaruh dari masing-masing variabel independen secara parsial terhadap variabel dependen. Untuk mengetahui bagaimana pengaruh tersebut dapat dilihat dengan membandingkan nilai probabilitas ( $p$-value) dari masing-masing variabel dengan tingkat signifikansi yang digunakan sebesar 0,05. Jika p-value lebih kecil dari 0,05, maka hal ini menunjukkan bahwa variabel-variabel independen secara parsial mempunyai pengaruh terhadap variabel dependen. Kriteria penilaian menggunakan degree of freedom $(\mathrm{df})=\mathrm{n}-\mathrm{k}$ dimana $\mathrm{n}$ adalah jumlah sampel dan k adalah konstruksi (variabel). Pada penelitian ini besarnya df =69-2 = 67 dengan $\alpha=0,05$ sehingga menghasilkan tabel $=1,667$. Dari tabel 4.10 hasil pengujian antara varaibel independen terhadap variabel dependen secara individual (parsial) adalah sebagai berikut :

Hipotesis pertama menyatakan bahwa Pemanfaatan Dana Zakat Produktif berpengaruh terhadap tingkat pendapatan mustahik. Dari tabel di atas dapat diketahui bahwa hasil pengujian untuk variabel Pemanfaatan Dana Zakat Produktif mempunyai probabilitas signifikan sebesar 0,000. Dari hasil output SPSS versi 22 nilai signifikan $0,000<0,05$ maka variabel bebas atau pemanfaatan dana zakat produktif $(\mathrm{X})$ berpengaruh signifikan terhadap variabel terikat atau tingkat pendapatan mustahik (Y). dapat disimpulkan bahwa Ho ditolak dan H1 diterima, yang 
artinya pemanfaatan dana zakat produktif BAZNAS Kota Palopo berpengaruh positif dan signifikan terhadap tingkat pendapatan mustahik.

\section{Pembahasan Hasil Penelitian}

Penelitian ini berusaha untuk memperoleh gambaran mengenai pengaruh pemanfaatan dana zakat produktif terhadap tingkat pendapatan mustahik pada BAZNAS Kota Palopo. Setelah menganlisis maka ditemukan bahwa pemanfaatan dana zakat produktif berpengaruh terhadap tingkat pendapatan mustahik, temuan ini dibuktikan dengan analisis data menggunakan metode penelitian yang telah ditentukan.

Hasil penelitian yang telah dilakukan dapat disimpulkan bahwa variabel pemanfaatan dana zakat produktif di uji secara parsial terhadap tingkat pendapatan mustahik pada BAZNAS Kota Palopo, hal ini ditunjukkan dengan nilai signifikannya 0,000 lebih kecil dari 0,05 menunjukkan arah hubungan yang searah (positif) artinya semakin sering pemanfaatan dana zakat produktif dilakukan maka tingkat pendapatan mustahik meningkat. Hal tersebut mendukung penelitian (Nafilah, 2015) menyatakan bahwa pemanfaatan dana zakat produktif berdampak positif terhadap peningkatan pendapatan mustahik. Begitupun penelitian yang dilakukan oleh (Pratama, 2015) yang menyatakan bahwa pemanfaatan dana zakat produktif berpengaruh positif dalam peningkatan kesejahteraan masyarakat (mustahik).

Berdasarkan hasil uji regresi linear sederhana diperoleh nilai b sebesar 0,783 hal ini berarti pemanfaatan dana zakat produktif mempengaruhi tingkat pendapatan mustahik sebesar 0,783 atau berpengaruh secara positif terhadap tingkat pendapatan mustahik.

Pemanfaatan dana zakat produktif adalah salah satu zakat yang diberikan kepada mustahik yang berhak menerimanya dan peningkatan pemasukan bagi mustahik yang menerimanya. Penulis menyimpulkan jika dana zakat produktif meningkat maka pendapatan mustahik juga akan meningkat. Dengan adanya modal maka pihak mustahik diharapkan dapat meningkatkan pendapatannya melalui usaha produktif dengan dana dari zakat yang mereka terima. Dengan menerima dana zakat produktif diharapkan pulan susunan masyarakat akan berubah atau dengan tujuan menjadikan mustahik menjadi seorang muzakki. Dengan ekonomi Islam zakat dapat meningkatkan pendapatan mustahik dan mengurangi ketimpangan pendapatan ekonomi dalam 
masyarakat, dengan adanya kebijakan alternative zakat diharapkan akan aka mekanisme transfer pendapatan antara orang miskin yang awalnya mengalami defisit.

\section{PENUTUP}

\section{SIMPULAN}

Berdasarkan data yang didapatkan setelah diolah data maka diperoleh hasil analisis penelitian mengenai pengaruh pemanfaatan dana zakat produktif terhadap tingkat pendapatan mustahik pada BAZNAS Kota Palopo, dari hasil penelitian yang dilakukan oleh penulis terhadap BAZNAS dan Mustahik maka dapat disimpulkan pendapatan mereka. Pemanfaatan dana zakat produktif $(\mathrm{X})$ mempunyai pengaruh signifikan terhadap tingkat pendapatan mustahik (Y) pada BAZNAS Kota Palopo. Hal ini dipekuat dengan adanya hasil uji T (parsial) dimana diperoleh nilai signifikan sebesar 0,000 lebih kecil daripada 0,05 yang berarti membuktikan hipotesis H1 diterima bahwa ada pengaruh signifikan pemanfaatan dana zakat produktif mempunyai pengaruh terhadap tingkat pendapatan mustahik pada BAZNAS Kota Palopo.

\section{SARAN}

Setelah mengadakan penelitian di Badan Amil Zakat Nasional Kota Palopo tentang pengaruh pemanfaatan dana zakat produktif terhadap tingkat pendapatan mustahik, maka berdasarkan apa yang sudah dialami penulis selama melakukan penelitian ini menyampaikan saran-saran sebagai berikut :

a. Bagi Badan Amil Zakat Nasional Kota Palopo, pihak BAZNAS Kota Palopo sebaiknya terus meningkatkan alokasi dana zakat untuk kegiatan produktif dalam rangka membangun perekonomian mandiri dan kesejahteraan para mustahik serta turut membantu pemerintah dalam hal pengetasan kemiskinan. Kemudian daripada itu agar pemanfaatan dana zakat lebih maksimal maka sebaiknya perlu diadakan pelatihan secara berkala, alat pelatihan, tempat pelatihan keterampilan pada BAZNAS Kota Paolopo, serta pemantauan berupa laporan keuangan agar lebih professional dalam menjalankan amanah ini.

b. Bagi para mustahik, dalam menggunakan dana zakat produktif agar benarbenar untuk usaha dan serius dalam menekuni usahanya, dalam rangka meningkatkan taraf perekonomian, tidak digunakan untuk kegiatan konsumtif yang kurang bernilai 
dedikasi agar tujuan dana zakat produktif itu tercapai makna pemberdayaan para mustahik.

c. Bagi peneliti selajutnya diharapkan memperhatikan indikator-indikator lain yang belum dicantumkan oleh penulis dalam penelitian ini.

\section{DAFTAR PUSTAKA}

Al-Ba'iy, M. A. . H. (2006). Ekonomi Zakat: Sebuah Kajian Moneter dan Keuangan Syari'ah. Jakarta: Raja Grafindo Persada.

Andri, S. (2009). Bank dan Lembaga Keuangan Syariah. Jakarta: Kencana.

Ascarya. (2006). Akad dan Produk Bank Syariah: Konsep dan Praktik Beberapa Negara. Jakarta.

Asnani. (2008). Zakat Produktif dalam Persepktif Hukum Islam. Yogyakarta: Pustaka Pelajar.

Assaggaf, M. A. (2016). Pengaruh Akuntabilitas Dan Transparansi Pengelolaan Zakat Terhadap Minat Muzakki Membayar Zakat (Studi Pada BAZNAS Kota Makassar Ruang LIngkup UPZ Kantor Kementrian Agama Kota Makassar).

Badan Pusat Statistik. (2018). Jumlah Penduduk Kota Palopo dan Agama yang di Anut Sensus Tahun 2018.

BAZNAS. (2018). Pebaznas No.3 Tahun 2018 Kelangsungan Usaha Mustahiq di Sulawesi Selatan. Jurnal PILAR, 2(2), 1-52.

Departemen Agama RI. (2004). Al-Quran dan Terjemahan Juz 1-30. Mekar Surya (Edisi Baru). Danakarya.

Fitri, M. (2017). Pengelolaan Zakat Produktif sebagai Instrumen Peningkatan Kesejahteraan Umat. Economica: Jurnal Ekonomi Islam, 8(1), 149.

Firmansyah. (2013). Zakat Sebagai Instrumen Pengetasan Kemiskinan dan kesenjangan Pendapatan. Jurnal Ekonomi Dan Pembangunan, 21(1), 179-190.

Geertz, C. (1973). Religion as a Culture System, Interpretation of Culters, Selected Essays. New York.

Hafidhuddin. D. (2002a). Panduan praktis tentang zakat infak sedekah. Gema Insani.

_. (2002b). Zakat dalam perekonomian modern. Gema Insani.

Hamdi, A. S. (2014). Metode Penelitian Kuantitatif Aplikasi dalam Pendidikan. Yogyakarta: Deepublish.

Hasan Muhammad. (2011). Manajemen Zakat (Cet.1). Yogyakarta: Idea Press. 
Indriantoro, N. supomo B. (2013). Metodologi Penelitian Bisnis. Yogyakarta: BPFE.

Kalbarini, Y. R., \& Suprayogi, N. (2014). Implementasi Akuntabilitas Dalam Konsep

Mahmudi. (2015). Penguatan Tata Kelola dan Reposisi Kelembagaan Organisasi Pengelola Zakat. Jurnal Ekbisi, 4(12), 69-84.

Miranda, G. E. (2018). Analisis Pengaruh Pendayagunaan Zakat Produktif Terhadap Perkembangan Usaha Mikro Mustahik (Studi Kasus Baznas). Diponegoro Journal of Economics.

Munir,M, Wahyu, I. (2009). Manajemen Dakwah. Jakarta: Kencana.

Muthohar, A. M. (2016). Preferensi Masyarakat Terhadap Lembaga Zakat Dan Bentuk- Bentuk Pemberdayaan Dana Zakat. Inferensi, 10(2),381-404.

Nafiah, L. (2015). Pengaruh Pendayagunaan Zakat Produktif Terhadap Kesejahteraan Mustahiq Pada Program Ternak Bergulir Baznas Kabupaten Gresik. 307(01), 929- 942.

Pedoman Zakat (4). (2010). Proyek Pembinaan Zakat \& Wakaf. Jakarta: Departemen Agama.

Pratama, Y. C. (2015). Peran Zakat Dalam Penanggulangan Kemiskinan (Studi Kasus : Program Zakat Produktif Pada Badan Amil Zakat Nasional). The Journal of Tauhidinomics, 1(1), 93-104.

Priyanto, D. (2011). SPSS Analisis Statistik Data Lebih Cepat Lebih Akurat. Yogyakarta: Medikom.

Ridlo, A. (2014). Zakat Dalam Perspektif Ekonomi. Jurnal Al-'Adl, 7(1), 119-137

Sartika M. (2008). Pengaruh Pendayagunaan Zakat Produktif terhadap Pemberdayaan Mustahiq pada LAZ Yayasan Solo Peduli Surakarta. Jurnal La_Riba, 2(1), 75-89.

Syafiq, A. (2015). Zakat Ibadah Sosial Untuk Meningkatkan Ketaqwaan Dan Kesejahteraan Sosial. Ziswaf, 2(2), 380-400.

Tohar, M. (2008). Membuka Usaha Kecil. Yogyakarta: Kansius

Ulza, E.. (2018). Strategi Pemberdayaan Pembangunan Sosial Melalui Gerakan Filantropi Islam. Al-Urban, 2(1), 32-42.

Utami. S, L. (2016). Pengaruh Pendayagunaan Zakat Produktif Terhadap Pemberdayaan Mustahiq di Kota Medan. Repositori Institusi Universitas Sumatera Utara, 1(2), 353-366.

UU No.23 Tahun. (2011). Tentang Pengelolaan Zakat. 